\title{
Park-people interaction - Its impact on livelihood and adaptive measures: A case study of Shivapur VDC, Bardiya District, Nepal
}

\author{
Narayan Prasad Paudyal \\ Central Department of Geography Education, Tribhuvan University, \\ Kathmandu, Nepal \\ Email:paudyal_narayan@yahoo.com
}

This paper deals with the concept of theoretical and conceptual framework in a research with park-people interaction of Bardiya National Park (BNP) with specific reference to Shivapur Village Development Committee (VDC) of Bardiya district. The local people enter the park illegally and exploit the park resources like fodder, firewood, thatch, etc. They also try to kill wildlife either for food as traditional profession or for money. They frequently encounter with wildlife and get injured; sometimes they are killed. Similarly, wildlife cross the park boundary and destroy the crops and kill the livestock. Villagers also get their shelters and sheds damaged by them. BNP, therefore, has introduced various programmes to keep the conservation intact without disturbing the livelihood of Buffer Zone people. Several efforts, such as construction of Trench, Machan etc. have been made to address the issues associated with park people conflicts. In addition, endowment funds, such as Rahat Kosh, Apatkalin Kosh and Chetipurti Kosh have been established to provide and compensate to the human casualty and property (mainly building) damage.The Park-People interaction is the reality and the need is felt from both sides. Despite ups (harmony) and downs (conflicts) and despite differential use of resources by localities, the interface continues and is likely to continue so long as both these entities exist there. The need is to realize eachothers limitations and strengthen their mutual understanding and the benefits.

Keywords: Interaction; impact; conservation; wild animal; buffer zone; national park 


\section{Introduction}

Human-nature relationship is not a new concept. Since long, human beings have interacted with nature to utilize natural resources for their basic needs. In the long run, population growth has caused excessive use of natural products resulting deforestation (Gurung, 1989). This has been mainly in response to the ever more apparent extent and severity of global environmental problems, which prompted various international agencies and national governments to search for a rational approach to the conservation of the natural ecosystem. The World Conservation Strategy (WCS) proposes an approach for the establishment of various representative coverage of the earth's wild species and major ecosystems. Resource conservation, as defined by the WCS, "is to maintain essential ecological processes and life support systems; preserve genetic diversity; and ensure the sustainable utilization of species and ecosystems" (Nepal \& Weber, 1993). As a result of this philosophy, many protected areas have been established.

The Yellowstone National Park, in the United States created in 1872 was the first National Park ever established in the modern world (Shafer, 1990). National Parks in the developing countries, particularly in Asia, were established in the beginning of the second quarter of this century (Mishra, 1991). In Nepal, to prevent the increasing rate of deforestation and to protect unique flora and fauna of this ecological belt, at first Chitawan National Park was established in 1973 (Upreti, 1991), after the declaration of the National Park and Wildlife Conservation Act, 1973 (2029 B.S.). Wildlife conservation has been successful from the viewpoint of habitats of several threatened species (Mishra, Wemmer, Smith \&Wegge, 1992). Active conservation of habitats has increased wildlife population within protected areas which started causing damage outside the park. The people living in and around such National Parks have interacted with them in multifarious ways. Some of them have built an ecological relationship with the park, whereas in certain other cases, the existence of National Parks has been questioned because of the growing conflict over land use rights and practices. The relation between park and people is imbalanced when the park animals damage and disturb the adjacent settlement. Damage of the agricultural crops, human harassment, injuries and death, livestock depredation are the common causes of this imbalanced relationship (Jnawali, 1989). Conflicts arise not only out of ecological malpractice but are also the reactions and social interventions from the outside (Jefferies, 1982; Weber, 1991).

For the first time, the Third World Congress on National Parks held in Bali, Indonesia in October 1982 focused its attention on the relationship between protected || $168 \mid$ 
areas and human needs and stressed the relevance of integrating protected areas with other major development issues (Mishra, 1991).This was reiterated during the Fourth World Congress on National Parks and Protected Areas held in Caracas, Venezuela, which called for innovative programmes of integrated planning and cooperative management at the bio-regional level that will support the roles of protected areas and directly involve the local residents and resource users (IV World Congress, 1992). According to the concept of park-people friendly environment, the periphery area of the park was declared as Buffer Zone minimizing the destruction caused by wildlife on human, shelter and crops. In Nepal, it was implemented in 1996 and in the same year it was provisioned in Bardiya National Park (BNP) which covers Shivapur VDC. This VDC lies in the Buffer Zone Area of BNP. This paper discusses park people interaction, its impact on livelihood and adaptive measures.

\section{Methods and materials}

In this research both qualitative and quantitative methods and techniques were applied to fulfill the research objectives. Focus Group Discussion, household survey using structural and semi- structural questionnaires, in-depth interviews, key-informant interviews and observation are the methods employed to generate primary data. Altogether, 105 households from Shivapur, VDC of Buffer Zone were selected randomly for interview. After the completion of household survey a total of five key informants were consulted to supplement the gaps of information. Selection of individuals for the interview was based on specific criteria such as gender, household and economic status. For the secondary information, a number of published and unpublished research documents, reports and theses and project reports on National Park and Buffer Zone were consulted. Descriptive Statistics was adopted. Besides these descriptive statistics, tables, bars, and maps are used to illustrate the findings.

\section{Study area}

The study area (Shivapur VDC) is located in Bardiya district which lies in western Tarai of Mid-Western Development Region of Nepal (Figure 1). Shivapur VDC is located between $81^{\circ} 16^{\prime} 30^{\prime \prime}$ to $81^{\circ} 19^{\prime} 24^{\prime \prime}$ East longitude and 28'28'02" to $28^{\circ} 31^{\prime}$ '03" North latitude. The total area of Shivapur VDC is 1415.11 hectares. According to 2011 Census, the total number of population in the study area is 7706 in which 3578 are males and 4128 are females. This area, the Tarai flatland, consists mostly of fine alluvial soil and loam whereas the riverine floodplain contains coarse sand and fresh deposits of alluvial soil, silt and gravel (Upreti, 1994). 


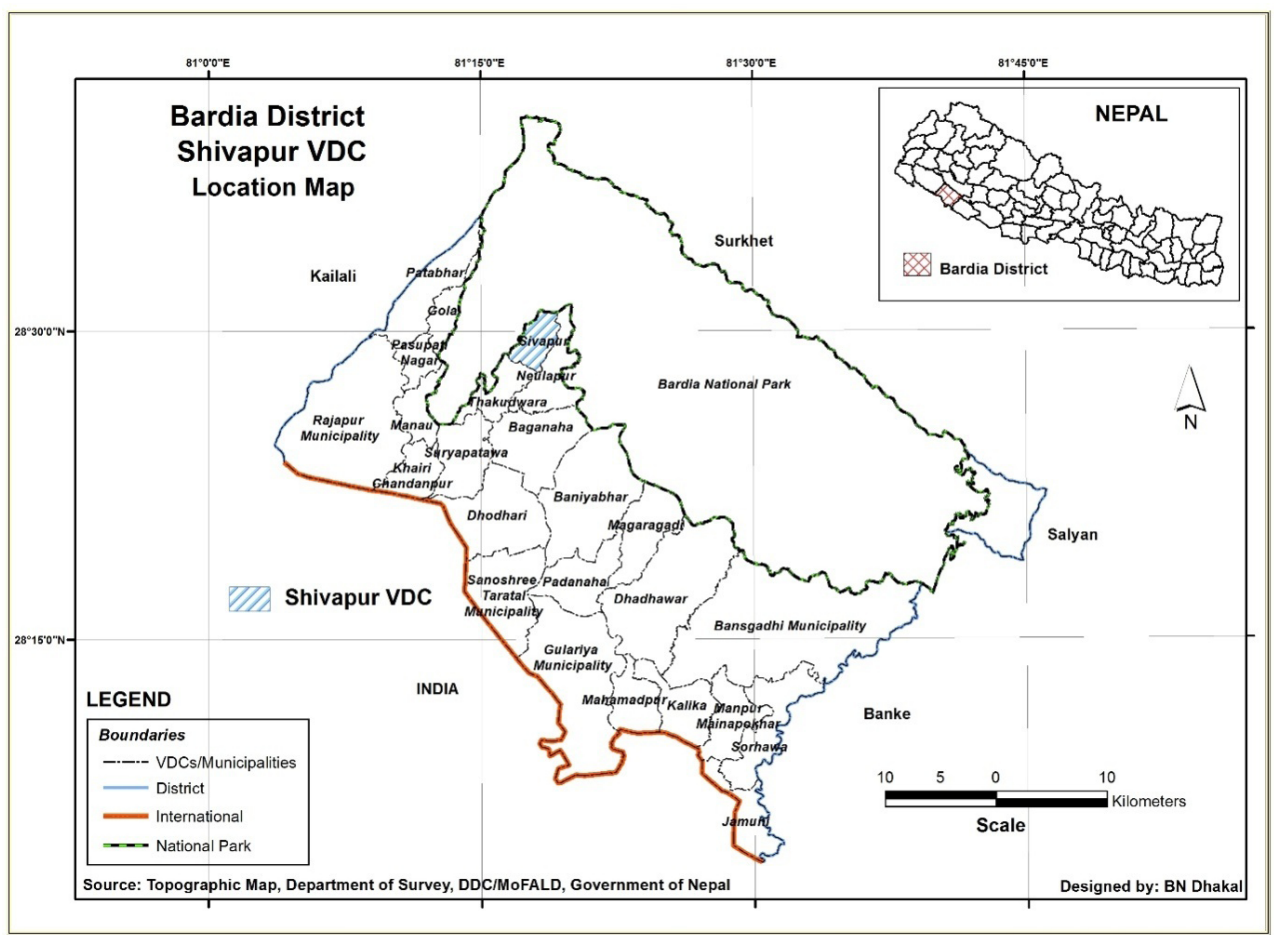

Figure 1. Location map

Three distinct seasons can be noticed in this area. These include: Spring from February to Mid-June, the monsoon season from Mid-June to late September, and the hot and dry season from late September to February. The mean monthly maximum temperature ranged from $17.4{ }^{\circ} \mathrm{C}$ in January to $38.5{ }^{\circ} \mathrm{C}$ in April and the mean monthly minimum temperature ranged from $9.7{ }^{\circ} \mathrm{C}$ in January to $25.6{ }^{\circ} \mathrm{C}$ in July. The maximum rainfall recorded at Chisapani- the nearest market of Shivapur was 864.6 mm. in 2010 (Paudyal, 2016).

\section{Results and discussion}

\section{Park-people interaction}

Park and people have coexisted for long and their co-existence is tied up in a special form of relationship considered as interface. This relationship or interface unfolds into several types of interactions and activities. Most of these interactions and activities are mutually benefiting although not all of theses activities benefit equally to both the parties. Buffer Zone people of Bardiya National Park have utilized various resources || $170 \|$ 
Narayan Prasad Paudyal / The Geographical Journal of Nepal Vol. 10: 167-180, 2017

like grass, fodder, timber, firewood, thatch, medicinal herbs and many others from the park and have adopted livelihood options accordingly for their living. On the other hand, wild animals from the park enter the villages to fulfill their hunger and ruin the crops. Residents of the Buffer Zone also disturb the natural course of action of wild animals in the park (BNP annual report, 2067/68). Despite these ups and downs in the relationships both parties have adjusted or adapted their living in and around the park areas.

\section{Impact of the park}

The people of study area (Buffer Zone) are victims of a host of problems raised by National Park. It has created two types of- direct and indirect-impacts on the life of VDC people. These impacts are given in detail in the following subsequent topics.

\section{Human casualty and harassment}

Encounter with wild animals around the park are common. Incidents of being knocked down by wild animals such as elephants, rhinoceros, leopards and wild boars are often discussed by the villagers. Each year, villagers of Shivapur VDC unfortunately lose their lives due to attack of elephant and rhinos in Shivapur VDC. According to Annual Report of Bardiya National Park (2010/11), one of the villagers from Shivapur in 2006 A.D was attacked by an elephant who was seriously injured. Similarly, in the year 2009 A.D. one fellow from the same VDC died due to elephant attack. Similarly, in the year 2010/11 four villagers were killed by the attack of wild animals in the Buffer Zone. Three of them were killed by elephants and one by the rhino. Among them one victim was from Shivapur. In Bardiya National Park, the number of elephants and rhinoceroses has increased from 60 to 80 and 15 to 24 respectively in five years.

Local harassment is another problem. In the evening it is risky to come out of houses because the elephants, rhinos, wild boars and other animals are freely visiting the fields nearby. Chasing them away may be dangerous and one often hears about someone being mauled, killed, or eaten away by the carnivores. Therefore, people move in groups to chase the wild beasts away.

\section{Crop damage}

Household Survey and Group Discussion in the study area entail that the main animals for damaging the crops are elephants, rhinos and chitals. On the other hand, other many 
Narayan Prasad Paudyal / The Geographical Journal of Nepal Vol. 10: 167-180, 2017

animals like wild boar, porcupines, rabbits and monkeys with birds are also responsible to destroy the crops in Shivapur. Paddy and wheat ready to harvest are destroyed by elephants and rhinos whereas chitals damage lentil and mustard. Likewise, vegetable grown fields are completely destroyed by wild boar, porcupines and rabbits. Monkeys, on the other hand, destroy maize including fruits and vegetables. The villagers are unwilling to grow wheat and maize because of such animals. The production of major crops and proportion damages by wild animals is given in the Table 1.

Table 1. Crop damage by wild animals

\begin{tabular}{|l|l|l|l|l|l|}
\hline Crops Type & $\begin{array}{l}\text { Number of } \\
\text { Households }\end{array}$ & $\begin{array}{l}\text { Production } \\
\text { (in quintal) }\end{array}$ & $\begin{array}{l}\text { Average } \\
\text { Per } \\
\text { Household }\end{array}$ & $\begin{array}{l}\text { Crop } \\
\text { Damage } \\
\text { (in quintal) }\end{array}$ & $\begin{array}{l}\text { Crop } \\
\text { Damage (in } \\
\text { percent) }\end{array}$ \\
\hline Paddy & 104 & 1800 & 17.30 & 1213 & 67.4 \\
\hline Wheat & 90 & 950 & 10.56 & 855 & 90.0 \\
\hline Mustard & 103 & 300 & 2.91 & 180 & 60.0 \\
\hline Maize & 30 & 50 & 1.67 & 40 & 80.0 \\
\hline Vegetable & 50 & 30 & 0.60 & 19 & 64.3 \\
\hline
\end{tabular}

Source: Field Survey, 2011

Table 1 shows the amount and types of crop production by household and the destruction caused by wild animals in a year. The highest number of household i.e. 104 and 103 grow paddy and mustard respectively and the production of each is 1800 and 300 quintals respectively. Of the total production about 67.4 percent paddy and 60 percent mustard is damaged by the park animals. Among the above mentioned crops, the destruction of wheat is more than that of other crops. Above 90 percent production is ruined by the animals. Only 30 households grow maize as maize is the most favorite food for animals and it is largely destroyed by wild animals. About 80 percent of the total production of maize is destroyed by them. The percent of damage of crops by type is shown in Figure 2. 


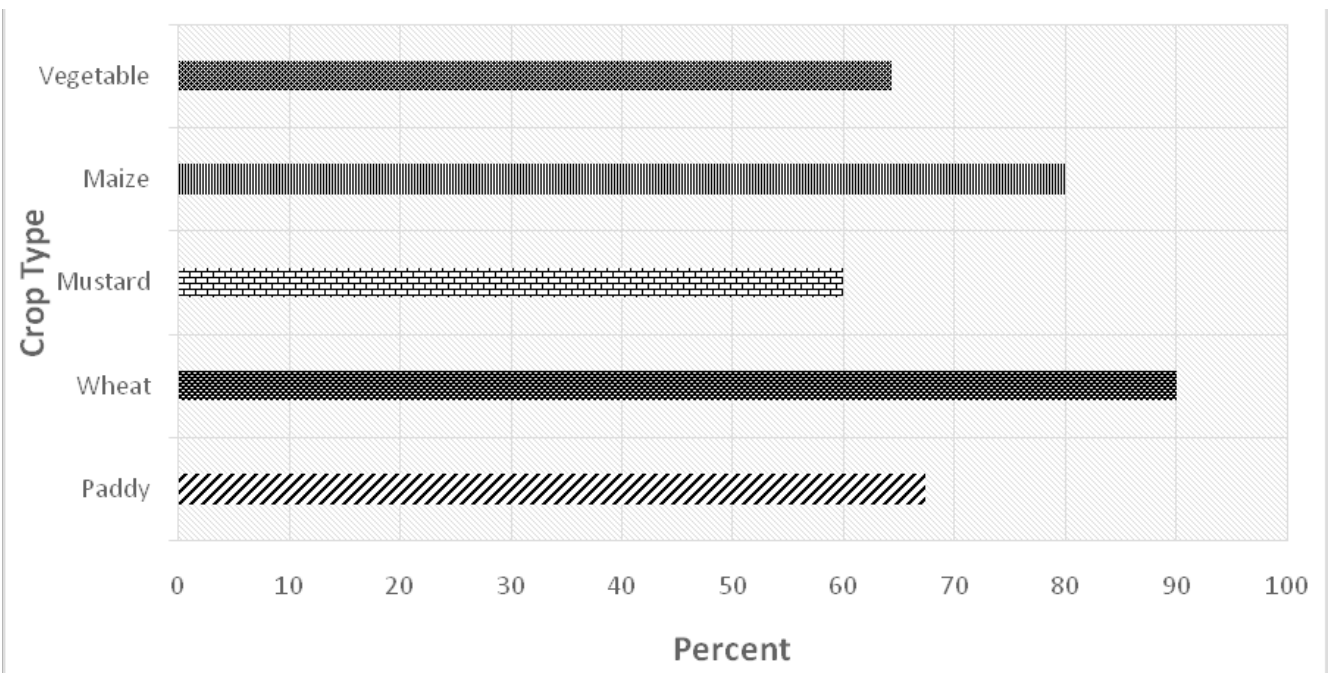

Figure 2. Crop damage (in percent)

\section{Livestock depredation}

Most of the farmers keep their own livestock. Cattle are an essential part of the Nepali agriculture system whose manure is used in the farms and he buffaloes and oxen are used for ploughing and transportation. Along with the problem of crop damage, livestock depredation is a severe problem in the study area. Livestock killing by carnivores has become a subject of discussion among villagers. About 10 percent villagers even expressed their feeling that hunting wild animals should be permitted in view of the loss incurred, which sometimes has cost them their income of a whole year or even more.

Domestic animals are restricted for grazing in National Park area so people take their animals for grazing to the open fields around their locality. Here mostly carnivorous wild animals like tigers, leopards and jackals make an encounter with domestic animals. Table 2 shows the number of animals encountered by wild animals on domestic animals in last five years in the study area.

Table 2. Number of livestock depredation by wild animals

\begin{tabular}{|l|l|l|l|}
\hline Type of Livestock & Number & Number of Depredation & Percent \\
\hline Cows & 151 & 6 & 3.69 \\
\hline Oxen & 122 & 4 & 3.28 \\
\hline Goats/Sheep & 463 & 51 & 11.01 \\
\hline Pigs & 78 & 6 & 7.69 \\
\hline Chickens & 826 & 16 & 1.93 \\
\hline Total & 1640 & 83 & 5.06 \\
\hline
\end{tabular}

Source: Field Survey, 2011 
Of the total 144 animals, 83 are killed among cows, oxen, goats, sheep and chickens. The depredation of goats/sheep by wild animals is higher than that of other animals. Of the total 463 , about 51 goats/sheep are killed which occupies 11.01 percent of the total killing. Similarly, the killing of pigs come in the second position i.e. about 7.69 percent are killed by park animals. In total 5.06 percent of livestock are killed by these animals.

\section{Tourism}

The number of tourist visiting BNP has increased from only 212 in 1984/85 to 8025 in 2010/11 (Figure 3). As a tourist spot of Nepal, tourism is gaining momentum in ThakurdwaraVDC in BNP every year. Shivapur is the adjacent VDC of Thakurdwara, the people of Shivapur are gaining its benefit on their social life after the establishment of the park which has brought about a great change in their culture, language, even in daily activities. For instance, the teenagers, after their schools, join a job in the hotels or lodges in Thakurdwara which has helped to improve their livelihoods.More than 200 villagers are engaged in tourism. While some of them are badly encouraged to take smoke and use hashish. After all they help their family throwing their earning from tourism. The prices of essential items have gone up due to the increased flow of tourists here. So, National Park has both positive and negative impact on their livelihood.

Figure 3. Number of tourist

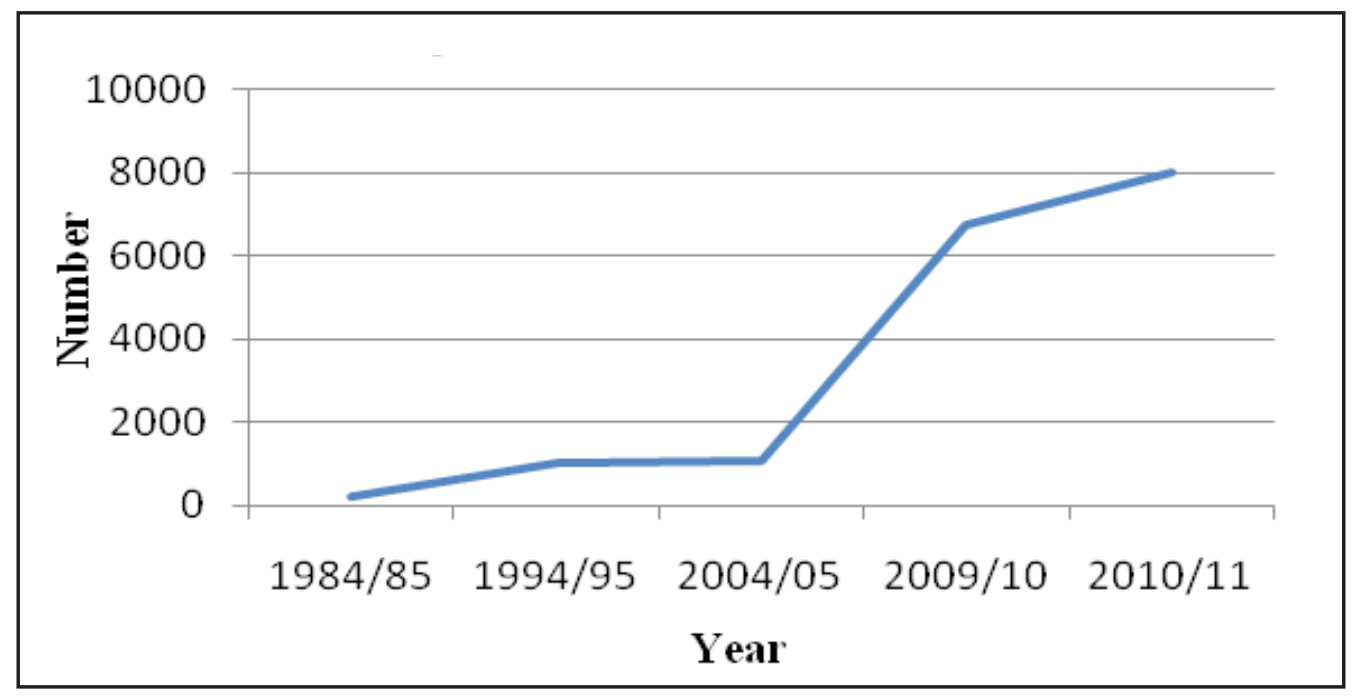




\section{Human impact on the national park}

Human impact has long-term consequences on the ecosystem of Bardiya National Park. Before the establishment of the National Park, there was some kind of positive interaction between the local people living in close proximity to the forests, because they utilized the land and resources there. Forest is the home of wildlife and resources, so the forest is used by both human beings and wild animals. When there is utilization of the same resources by two kinds of individuals, there is interaction and competition between them. While entering the forest to fulfill their requirements, people usually damage and destroy the habitat of wildlife and these animals do not tolerate human interference. These animals also cause economic losses through their raids into the farm lands and villages. People sometimes kill the wild animals and harm the miscellaneous forest products. The park once was utilized as common place for commercial forestry by the local people. So, clearing of forest land for agriculture, grazing of livestock, lopping of trees, burning of grasses, and collection of thatch have all contributed to the formation of the present environment of the park. Of the major impacts in the study area is the illegal exploitation of park resources by villagers living adjacent to the park. According to the information obtained, the human impacts to park listed by the local people are as follows:

\section{Hunting and poaching}

Indiscriminate poaching of wild animals such as sambar (Cervusduvauceli), bluebull (Baselaphustragocamelus) and sloth bear (Melursusursinus) has reduced the size of their population. Poaching of endangered species such as tigers (Patheratigris) and leopards (Pantheraparadus) by poisoning are frequently suspected to occur in the park. Cases of rhinoceros (Rhinoceros unicornis) and tiger poaching have also been recorded in Bardiya National Park (Upreti, 1994). According to annual Report of Bardiya National Park 2067/68, 57 illegal activities like hunting, poaching, wood thefts etc. have occurred during the year. Of the total such activities, 17 are related to hunting and poaching and one of which happened in Shivapur. Due to the fright of concerned security personnel of National Park, people seemed unwilling to provide the actual data on hunting and poaching during household survey. However, group discussion showed that some animals such as deer, rabbits, porcupines, bluebulls are killed during crop raiding. 


\section{Firewood and other forest products}

The important resources required to make a living possible for the households in the Park neighborhood are a steady supply of firewood, construction and repair materials for their thatched house,timber for agricultural implements and other forest products. The main five items the local people extract from the Parks either legally and illegally are firewood, timber, thatch/grass and Babio. They also extract wild edibles such as mushrooms, roots and Siplicanas vegetables occasionally. The main park products used by households are shown in Table 3.

Table 3. Park products used by households

\begin{tabular}{|l|r|l|l|}
\hline Item & $\begin{array}{l}\text { Consumption per } \\
\text { household per year }\end{array}$ & $\begin{array}{l}\text { Collection from } \\
\text { BNP per household } \\
\text { per year }\end{array}$ & $\begin{array}{l}\text { Percent of } \\
\text { collection from } \\
\text { NBP in total } \\
\text { consumption }\end{array}$ \\
\hline Firewood $(\mathrm{kg})$ & 3600 & 3400 & 95.00 \\
\hline Timber $\left(\mathrm{m}^{3}\right)$ & 500 & 300 & 60.00 \\
\hline Grass $(\mathrm{kg})$ & 3000 & 2600 & 86.66 \\
\hline Babio $(\mathrm{kg})$ & 300 & 300 & 100 \\
\hline
\end{tabular}

Source: Field Survey, 2011

As shown in Table 3 about 95 percent firewood requirement is fulfilled from the National Park. Rest 5 percent of the fuel wood needs are made from resources such as utilization of agricultural refuses, dung cake, bio-gas and trees planted on private land. Similarly, the National Park fulfills 60 percent timber needs of the household. About 73.3 percent households in the study area use thatch as roof materials which are extracted from the park (Paudyal, 2016).

\section{Grazing/encroachment}

Livestock husbandry plays a valuable role in the farmer's economy. Nepalese farmers keep large numbers of domestic animals especially for the production of manure, food products. Cows provide milk, butter and other milk products. Other livestock such as buffalo and goat/sheep contribute as an important source of meat for dietary protein. 
Narayan Prasad Paudyal / The Geographical Journal of Nepal Vol. 10: 167-180, 2017

According to household survey, 95 percent farmers selectively stall-feed their livestock. Those animals which are not stall-fed are generally let loose in the morning and driven to nearby grazing grounds including forest, community lands, and agriculture fields during fallowing, and floodplains. Although illegal, some of these livestock are taken to the adjoining park land on almost regular basis. Even those which were stall-fed are generally taken to the nearby watering place. Green fodder, grass or leaves, are brought home for the stall-fed animals. Fodder is harvested from various sources depending upon the season, including nearby community forest, floodplains and farmer's own land. Although illegal, about 86.66 percent fodder is harvested from the park forests. The population of livestock captured is relatively high during the dry months of the year when people take their livestock inside the park for grazing when there is lack of the grass outside the park.

\section{Forest fire}

Forest fire is a desirable tool for management provided that it is scientifically used. It can be used to improve the quality of the natural habitats of animals and provide nutritional food to those animals. In Bardiya National Park and elsewhere, grasslands are set on fire illegally by villagers while collecting reeds during the grass-cutting season. It does help new grass and plants to grow but it also destroys plants and animals species. According to Tikaram Adhikari- the park warden, Bardiya National Park sets fire on grass once a year after the collection of reeds and thatch so that new shoots can grow easily.

\section{Adaptive measures}

To keep the wild animals at bay, villagers have applied a number of traditional techniques which were observed during the field survey. Some measures used in the study area are applied in collaboration with National Park by the villagers. National Park has invested some amount of money and rest of amount needed for it is spent by the villagers to construct the various items but for some, the community itself has funded. By the joint investment of National Park and community, barbed fence, machan and trench are constructed. For the construction of such things National Park provides technical support and essential materials, e.g. timber, wire. While community provides labour free of cost. For the protection of crops, the villagers become active. They individually use different techniques for this purpose. Scare crow, ringing bell, translocation and 
Narayan Prasad Paudyal / The Geographical Journal of Nepal Vol. 10: 167-180, 2017

killing are some of individual adoptive measures. The people have used the following techniques which are shown in Table 4.

Table 4. Measures adopted by people

\begin{tabular}{|c|c|c|c|}
\hline \multirow{2}{*}{ Techniques } & \multirow{2}{*}{ Units } & \multicolumn{2}{|c|}{ Benefitted households } \\
\hline & & Number & Percent \\
\hline Barbed Wire (km) & 10 & 105 & 100 \\
\hline Machan (number) & 12 & 98 & 93.3 \\
\hline Trench (number) & 10 & 99 & 94.3 \\
\hline Scar Crow (number) & 50 & 102 & 97.1 \\
\hline Ringing Bell (number) & 2 & 5 & 4.8 \\
\hline
\end{tabular}

Source: Field Survey, 2011

By the joint investment of National Park and Buffer Zone community barbed wire, machan and trench have been constructed. While observing these things in study area, cent percent sampled households are benefitted by Barbed Wire facility. Machan, one of the methods of protecting crops, has facilitated 93.3 percent households. About 94.3 percent households are involved in construction of trench in Shivapur. The more common techniques used by the villagers are scare crow, and ringing bell. Ringing bell, a new technique among other techniques, has been more popular in chasing the beasts. About 4.8 percent households in study area use this technique. The number and length of each technique is given in Table 4 in detail.

Although various techniques have been used by the villagers with joint venture of BNP to stop animal from entering the villages but these techniques have not completely worked. In other words, no technique is hundred percent effective to confine animals inside the park.

\section{Conclusion}

Park people interaction includes both positive and negative interface between the both aspects. People living adjacent to or around Bardiya National Park try to exploit the natural resource flora and fauna for their livelihood.On the other hand, Park stops people from doing such indiscriminate consumption of natural products. As a result, more interaction occurs between park and local people. For inhabitants of Shivapur 
Narayan Prasad Paudyal / The Geographical Journal of Nepal Vol. 10: 167-180, 2017

VDC forest products are taken for granted to them. When park authorities ban them from their traditional rights of using goods from the park they show their strong reaction and illegally enter the park.

On the other hand, the people have been the victims of a host of problems raised by Park since it has affected the people mainly in two ways that are characterized as direct and indirect impacts. The main impacts are human casualty, house and cattle-shed damage, crop damage, livestock depredation, incidences of spotted rule violations, local harassment and transition in socio-cultural rituals. There is no one way impact of Park to local people but these people have also affected the Park with their malpractice. The local people kill wild animals indiscriminately. Their illegal activities of hunting and killing have reduced the numbers of endangered animals like tigers and rhinos. People very often enter the park illegally for collecting firewood, thatch and forest products. They also set fire illegally in the forest due to which many innocent wildlife and plants get burnt.

The people of the study area have applied various techniques for avoiding the entrance and attack of wild animals so that human casualty and crop damage can completely be stopped. Barbed fence, machan, trench, scare crow and ringing bell are the techniques applied by the local people. For the very purpose, Park has assisted people financially or by providing essential materials from the park.On the whole, both the people of the study area and the Park authorities have struggled simultaneously for better livelihood and wildlife conservation respectively without disturbing each other as far as possible. Keeping the Conservation Areas intact without compromising the customary livelihood of the people in the vicinity has become an important issue of managing such areas.

\section{References:}

Gurung, H. (1989). Dimensions in development. Kathmandu:Sahayogi.

Jefferis, B. E. (1982). Sagarmatha national park: The impact of tourism in the Himalayas. Ambio. 11(5): (pp. 274-281).

Jnawali, S.R. (1989). Park-people conflict: Assessment of crop damage and human harassment by rhinoceros (Rhinoceros unicornis) in Saursha area adjacent to the royal Chitawan national park,Nepal.Unpublished PhD. Dissertation, Agricultural University of Norway. 
Narayan Prasad Paudyal / The Geographical Journal of Nepal Vol. 10: 167-180, 2017

Jnawali, S. R. (1994). Conflict of land use: livestock management and community forestry in Bachhaui village development committee adjacent to royal Chitawan national park in lowland Nepal. M.Sc. Thesis, Agricultural University of Norway.

Mishra, H. R. (1991). Regional review: South and south-east Asia. A review developed from a regional meeting on national parks and protected areas held in Bangkok from 1-4 Dec. 1991 under the co-sponsorship of IUCN, AIT and the World Bank.

Mishra, H. R., Wemmer, C., Smith, J. L. D.,\&Wegge, P. (1992). Bio-politics of saving Asian mammals in the wild: Balancing conservation in developing countries- A new approach. In P. Wegge (Ed.), NORAGRIC occasional paper, 11:(pp. 9-35).

Nepal, S. K., \& Weber, K.E. (1993).Struggle for existence: Park and people conflict in Chitawan national park. Bangkok: Asian Institute of Technology.

Paudyal, N. P. (2016), Livelihood in buffer zone: A study of park-people interface in Bardiya national park.Unpublished PhD. Disseratation, Tribhuvan University of Nepal.

Paudyal, N. P. (2016), Tourism in Nepal: Trends, Patterns and Major Attractions of Bardiya national park.Central Department of Geography Education.The Third Pole, vol. 14-16: (pp. 27-32).

Shafer, C. L. (1990). Nature reserves: Islands theory and conservation practice. Washington D.C.: Smithsonian Institute Press.

Upreti, B. N. (1991). Natural heritage of Nepal.Natural and cultural heritage in Nepal. Proceedings of the workshop on the conservation of heritage of national significance, Kathmandu, Nepal. National Conservation Strategy Implementation Project, Kathmandu: National Planning Commission and IUCN.

Upreti, B. N. (1994).Bardiya national park. Kathmandu: National Conservation Strategy Implementation Project.

Weber, W. (1991). Enduring peaks and changing cultures: The Sherpas and Sagarmatha (Mount Everest) national park. C. W. Patrick \& R.B. Steven (Eds.), Resident peoples and national parks. Social dilemmas and strategies in international conservation. (pp. 206-224). Tucson: University of Arijona press. 